\title{
THE MANAGEMENT OF E-LEARNING PLATFORMS AND ONLINE ASSESSMENT IN PRIMARY EDUCATION THROUGH THE PRISM OF SCHOOL ENGAGEMENT AND SCHOOL CULTURE
}

\author{
Jon Xabier Basogain Urrutia \\ Toki Eder Ikastola \\ jonxabier.basogain@tokieder.eus, ORCID 0000-0002-1454-6798
}

\begin{abstract}
In recent years, e-learning has been a very relevant and interesting object of research for the educational community. However, it has been mainly focused on its pedagogical side, leaving aside the more technical aspect. In this paper, virtual learning environments will be approached from a more technical point of view, focusing on their implementation, management and maintenance. In addition, in a context in which the real value of exams has been questioned, alternatives to them will be offered and an approach to online test supervision tools (e-proctoring) will be made. All this will be discussed within the framework of primary education where e-learning and the management of Virtual Learning Environments will also be addressed through the concepts of school engagement and school culture.
\end{abstract}

Keywords: e-learning, management, online assessment, primary education, school engagement, school culture.

\section{INTRODUCTION}

E-learning has become not only a tool to improve the quality of education, but also the axis of many learning environments. It could be thought that the huge growth of educational technologies happened in the last year due to the coronavirus (SARSCoV-2) pandemic, but this is not completely true. While the pandemic made all the learning turn virtual, the educational technologies existed many years before 2020 . In Spain, for example, in 1999, the University of La Rioja started an online teaching program; and the University of the Basque Country made Moodle their learning platform by 2010 (Moreno \& Santiago, 2003; Ros, 2008).

These two cases are just small examples that symbolize the technological revolution that our world witnessed in the late '90s. By 2020, e-learning was just part of our culture, giving rise some years before among other elements related to the e-learning culture, to the so-called "online universities". These colleges were born with the 
objective of fully online teaching university degrees and master's degrees, but the real origins of distance learning dates back to 1969 with the creation of the Open University in the UK (Szulc, 2020).

Online universities have a great deal of students from all around the world. In Spain, for example, there are two big universities that are fully dedicated to online teaching: the International University of La Rioja (also known as the "University on [the] Internet") and the Valencian International University. As the main goal is online teaching, there are some differences between them; while the Valencian International University assesses their students online using a program based on artificial intelligence, the International University of La Rioja calls for on-site exams (Periódico La Rioja, 2019; Universidad Internacional de Valencia, 2020; Universidad Internacional de La Rioja, 2015).

This 'the online teaching being a revolutionary method in the late ' $90 \mathrm{~s}$, the online Universities and the e-learning platforms as an essential part of the face-to-face learning for more than a decade' is just evidence that proves that the means to teach and assess online were in our schools and universities long before the pandemic. Even so, it is considered that the forced transition to online teaching was difficult and laborious and yet not as successful as expected (Abreu, 2020).

There are two reasons that can help explain why the e-learning environments did not work as expected. First, it is very important not to focus only on universities, and understand the special characteristics of the learning and teaching processes in early ages where e-learning is not an option ( $0-6$ years). Second, elearning needs to be understood as the tool it is and the new opportunities it brings, and not as a tool only used to reproduce traditional teaching and assessment methods (Ananga, 2020). In Primary Education, e-learning platforms were not as used as in universities or high schools, resulting in teachers not having enough technical knowledge to set up (and in some cases create) virtual learning environments. While universities and big corporations had experience and specialized people creating, maintaining and supervising the technical aspects of Learning Management Systems (LMS), primary education teachers had to do everything by themselves and take care of not only the pedagogical aspects but also of the technical ones.

Then, the traditional assessment methods were once again questioned (López-Alvarez, 2013; Jiménez et al., 2017; Kharbat \& Daabes, 2021). The real value of a final test, especially in situation where 'in primary education' there were no means to supervise online exams (e.g. e-proctoring programs). Alternatives to these types of tests were being proposed, as well as e-learning methodologies, such as gamification were on the rise.

In this paper, the major two concerns raised in the previous lines (management of LMS platforms) and online assessment are going to be addressed, always in the context of primary education. In addition, the relevance of e-learning in school culture and school engagement are going to be taken into account.

For this purpose, a theoreticaldescriptive review study will be carried in which the existing theory will be reviewed, in order to know how LMS Management aspects were approached in the educational-scientific literature. 
In the review of scientific literature, it was found that there are very few studies that analyze e-learning from a technical point of view. Studies on the validity and effectiveness of e-learning in university contexts predominate, with hardly any research conducted in primary education. It is precisely in primary education where it is most important to carry out investigations and case studies on the application of e-learning platforms from a technical point of view. This is because primary schools, which are the ones who create their own VLEs, do not have a team of computer scientists and IT experts, unlike universities.

Therefore, the main objective of this paper provides the educational community with a technicalpedagogical reference framework that allows the installation and management of LMS in primary education centers, as well as their pedagogical integration in the teaching-learning processes and school culture. This chapter carries out a qualitative observational study, analyzing the data obtained in a theoreticaldescriptive method, in order to systematize them and elaborate a multidisciplinary approach that brings together various technical and pedagogical aspects.

\section{THE MANAGEMENT OF E-LEARNING PLATFORMS (LMS)}

In the introduction, management of e-learning platforms was considered one of the major topics to address. Many primary education schools have no specialised teachers that have the technical knowledge to manage a LMS site such as Moodle. What is more, they cannot choose the most suitable LMS for the school due to the poor information that schools have regarding this issue.

\subsection{The need to choose a good LMS: Moodle, Google Classroom and BlackBoard Learn}

Nowadays, there are three big e-learning platforms: Moodle 'free', Google Classroom 'free for schools using Google Workspace for Education' and BlackBoard Collaborate 'pay' (Basogain-Urrutia, 2021). All of them have pros and cons, and it is essential for schools to know them, so they can freely choose their ideal LMS. A big problem nowadays is that many schools are using Google Classroom just because it is part of their Google Workspace for Education, resulting in a disadvantage for Moodle and BlackBoard Learn. Google Workspace for Education provides an institution with a mailing system for unlimited users, which is the main reason that schools find Google and then they end up using their virtual classrooms because there is no need to register the users (the login is the same as in the corporate email).

The ideal situation, however, would be that a school depends on no company to set up its own Virtual Learning Environment (VLE). This is only the case with Moodle (Modular Object-Oriented Dynamic Learning Environment), which, as a public domain software or shareware, makes it possible for a school to install it and freely use it. A possible issue could be that Moodle needs to be installed in the main server of the school, and, as it needs to be accessed from outside the school, this could bring some security issues, because school servers do not have as much security as big corporate servers have. 
Even so, Moodle is such an excellent LMS platform and the security problem could be solved just by using a hosting server and not installing the program in the school server. Hosting a website is not free, but some governments such as the Basque government (Eusko Jaurlaritza) offers an e-learning hosting platform with secured servers to provide Moodle to the schools in the Basque Autonomous Country. BlackBoard Learn is a very similar to Moodle, but it requires an institution to pay a fee, so it is not considered an ideal option for a school, so, there is no other but Moodle and it is the ideal LMS for a school. In table 1 is displayed a brief comparison of the VLEs mentioned in this chapter.

Table 1. Comparative of Google Classroom, Moodle and BlackBoard Learn

\begin{tabular}{|c|c|c|c|}
\hline & Google Classroom & Moodle & BlackBoard Learn \\
\hline Zero cost & $\begin{array}{l}\text { Yes, but when using } \\
\text { Google Workspace for } \\
\text { Education. }\end{array}$ & Yes. & No. \\
\hline $\begin{array}{l}\text { Set up and } \\
\text { maintenance }\end{array}$ & $\begin{array}{l}\text { Software as a Service. } \\
\text { Installed in Google's } \\
\text { servers. No mainte- } \\
\text { nance. }\end{array}$ & $\begin{array}{l}\text { Needs to be installed } \\
\text { in an own server. } \\
\text { Needs to be updated. } \\
\text { Hosting is possible. }\end{array}$ & $\begin{array}{l}\text { Software as a Ser- } \\
\text { vice. No mainte- } \\
\text { nance. }\end{array}$ \\
\hline $\begin{array}{l}\text { Site admin } \\
\text { privileges }\end{array}$ & $\begin{array}{l}\text { Admin needs to be } \\
\text { invited to classroom to } \\
\text { see its content. Only } \\
\text { can see number of } \\
\text { active classrooms and } \\
\text { can choose what users } \\
\text { can create classrooms. }\end{array}$ & \multicolumn{2}{|c|}{$\begin{array}{l}\text { Admin can see and edit all the classrooms. } \\
\text { Only admins can create classrooms (can } \\
\text { connect with a database and create them } \\
\text { automatically). } \\
\text { Can see and edit all classrooms. }\end{array}$} \\
\hline Appearance & $\begin{array}{l}\text { Pre-determined by } \\
\text { Google. Can only } \\
\text { change the heading } \\
\text { picture of a classroom. }\end{array}$ & \multicolumn{2}{|c|}{$\begin{array}{l}\text { The whole site can be personalized (col- } \\
\text { ours, fonts, shapes, institutional logotypes, } \\
\text { course descriptions, display the names of } \\
\text { the teachers)... }\end{array}$} \\
\hline $\begin{array}{l}\text { Tools and } \\
\text { plugins }\end{array}$ & $\begin{array}{l}\text { Connected to all } \\
\text { the Google services } \\
\text { such as Drive and } \\
\text { can create templates } \\
\text { for assignments and } \\
\text { each student's work is } \\
\text { automatically saved in } \\
\text { the classroom's Drive } \\
\text { folder. }\end{array}$ & $\begin{array}{l}\text { Can add plugins } \\
\text { to use determinate } \\
\text { software compatible } \\
\text { with Moodle (text } \\
\text { editors, voice record- } \\
\text { ers, videoconference } \\
\text { tools such Black- } \\
\text { Board Collaborate } \\
\text { Ultra). }\end{array}$ & $\begin{array}{l}\text { Need to use its } \\
\text { resources but can } \\
\text { connect with other } \\
\text { software when us- } \\
\text { ing LTI (Learning } \\
\text { Tools Interoperabil- } \\
\text { ity) which allows } \\
\text { services to inte- } \\
\text { grate in the LMS. }\end{array}$ \\
\hline $\begin{array}{l}\text { Videoconference } \\
\text { tools }\end{array}$ & $\begin{array}{l}\text { Google Meet integrat- } \\
\text { ed in Classroom. }\end{array}$ & $\begin{array}{l}\text { Can add plugins } \\
\text { or LTI to use them } \\
\text { (license may be } \\
\text { required). }\end{array}$ & $\begin{array}{l}\text { BlackBoard Col- } \\
\text { laborate Ultra } \\
\text { integrated. }\end{array}$ \\
\hline
\end{tabular}




\subsection{The Management of Moodle in Primary Education}

As important as a good choice of a good LMS platform for the school is its management. In the previous section, Moodle was chosen as the best LMS for a school as it is shareware and offers multiple customizable options, all of it at no cost and it depends on no private companies. One of the problems that schools have regarding the installation of a LMS is that teachers and ICT coordinators have no specific training in the installation, management and maintenance of an LMS. Therefore, the management of these sites is usually poor, follows no order and depends on each teachers' criteria. This sub-chapter is going to address this issue as it may recommend some basic steps to use and manage Moodle as a site administrator.

A big difference that Moodle and Google Classroom have is that Moodle requires each course to have a minimum set of information that works not only as a tool to arrange the courses, but also as an ID. Courses can be also arranged in categories (e.g., grades, stages, topics, etc.) while in Google Classroom courses have no ID nor categories, these two items will make easier to manage e-learning sites.

\subsubsection{Basic setup: users, courses and categories.}

Users need to have login credentials in Moodle. Those login credentials can be given by the site admin or an auto-login form can be added to the login site so each user can create a profile. Also, there is the option of "guest" user, requiring no login credentials, but the site admin can disable this option.

Courses are the axis of every LMS, in the case of Moodle, only the site admin or the persons designated by the admin can create courses. There is an option that allows other users to request new courses. This option is displayed as a form where the person requesting the course needs to introduce all the information regarding the course. The form is customizable by the site admin and can add additional fields regarding other aspects (e.g., questions like, "What do you need this course for?").

When creating a course, the course must be given a full and a short name. The full name is displayed on the home page and in the heading of the course; while the short name is shown only when navigating in the left bar and it is used as an ID of the course because the real ID is never visible to the users. Courses can be arranged in categories and when creating a course, needs to be nested in a category.

\subsubsection{Management: users, courses and categories}

Everything in Moodle can be done manually, but it is not useful when it comes to big schools when up to 200 students and teachers need to be enrolled in courses, and more than 20 courses and categories need to be created. Moodle provides easier ways to substitute all these manual methods with massive operations. An ideal situation would be that schools had databases such as Oracle with Lightweight Directory Access Protocol (LDAP) authentication. In this ideal situation, it would even be possible to have a virtual classroom management program that reads the data relating to students, teachers and their subjects and automatically creates virtual classrooms for each school year. This would allow immediate changes in Moodle at the same time they happen in the database (e.g., a student changes groups, there is a new substitute teacher...). 
As long as this option is not a real option, there are other ways to manage Moodle and enact massive changes easily. Thanks to Microsoft Excel, a list of users, courses, and categories can be created and with Moodle's option to use this type of upload option - massive users, courses and categories, everything can be set on a file and Moodle will to the job. But before doing so, each school needs to set its own rules and formats, as the example shows in table 2 :

Ta b le 2. Setting users, courses and categories in Moodle: examples of formats

\begin{tabular}{llll}
\hline & \multicolumn{1}{c}{ Rule } & \multicolumn{1}{c}{ Format } & \multicolumn{1}{c}{ Example } \\
\hline Name & $\begin{array}{l}\text { Name and surnames (both) need to } \\
\text { be registered in Moodle. No short } \\
\text { names, nor only one last name are } \\
\text { going to be accepted. }\end{array}$ & $\begin{array}{l}\text { Name } \\
\text { Surname1 } \\
\text { Surname2 }\end{array}$ & $\begin{array}{l}\text { Jon Xabier } \\
\text { Basogain Urrutia }\end{array}$ \\
\hline $\begin{array}{l}\text { Full } \\
\text { name of } \\
\text { a course }\end{array}$ & $\begin{array}{l}\text { The name subject, it includes no } \\
\text { other information (grade or group). }\end{array}$ & $\begin{array}{l}\text { Full name of } \\
\text { the subject }\end{array}$ & $\begin{array}{l}\text { Basque Language } \\
\text { and Literature }\end{array}$ \\
\hline $\begin{array}{l}\text { Short } \\
\text { name }\end{array}$ & $\begin{array}{l}\text { Includes a short name of the subject, } \\
\text { the school year, grade and group. }\end{array}$ & $\begin{array}{l}\text { 2021-22__ } \\
\text { Shortname_ } \\
\text { Grade-Course }\end{array}$ & $\begin{array}{l}\text { 2021-22_Basque } \\
\text { LH5-A }\end{array}$ \\
\hline Category & $\begin{array}{l}\text { Must make reference to a big group } \\
\text { of courses (e.g., all the courses of } \\
\text { fifth grade). }\end{array}$ & $\begin{array}{l}\text { Main } \\
\text { category/Sub- } \\
\text { category }\end{array}$ & Primary Education/ \\
& & & \\
\hline
\end{tabular}

Source: Own work.

It is important that when creating the .cvs or .xls file to upload the users and courses, these format-rules are followed. In addition to the options mentioned before, there is also the option to specify the role of the user on each course, a group (if groups are being used on each course) and many more options. It is important to remember that if one user already exists in the Moodle site, when uploading the file with users and courses, that user's profile is going to be updated, which makes this option an excellent substitute for more complex systems.

\section{ONLINE ASSESSMENT}

Moodle and similar LMS sites offer many different ways to assess students online. In fact, in Moodle not only "quiz", which the tool to create online exams, and "assignment" are used to assess students. Other tools such as "forum" or "lesson" are used to assess as well because they can be graded. When classes were suspended due to COVID-19 pandemic, the real value of the exams and traditional assessments was questioned. In this chapter, alternatives to traditional exams and assignments will be analysed (both in and out of Moodle). Yet, traditional exams and other types of tests such as practical exams need to be proctored, so e-proctoring techniques will be analysed as well. 


\subsection{Alternatives to traditional assessment methods}

Inside Moodle there are three resources that can be used to assess students as alternatives to traditional evaluation resources:

1. Forum. The forum activity module enables participants to have asynchronous discussions (Soliman, 2014). A teacher can set different topics and students can discuss them.

2. Lesson. The lesson module includes theoretical explanations of a teacher and multimedia content (texts, videos, pictures...) and questions regarding the theory.

3. Peer to peer assignments. When using this module, assignments sent by the students are going to be graded not only by the teacher but also by another classmate. The weight that a peer's grade has on the final grade of the assignment varies as established by the teacher and can range from zero to 100 percent.

As demonstrated, tools that do not seem oriented to assessment can be useful in Moodle, but when it comes to more pedagogical aspects and changes related to the teaching approach, there are some alternatives that are very useful too.

1. Portfolio of activities. The aim is to highlight the work done in the subject during the course, seeking to develop tests that put the students' knowledge to the test, making them find solutions and acquire disciplinary and interdisciplinary competencies (Gregori \& Martín-Rojo, 2011).

2. In-class activities. It is equally useful, as well as enriching, to create debates in class where students must present their arguments for or against a question or problem proposed by the teacher. Thus, the student will have to position himself, argue and give his opinion based on facts and theoretical knowledge. These activities can be both formal (previously planned) and informal (arising in class).

3. Final project. As a culmination of the course, the final project is a good choice. This project can be a research paper (e.g., exposing the most relevant discoveries of Fleming) or a more creative activity such as sending letters to the characters of a book read in class from the point of view of a friend of the character, commenting on something that happened in the story. It can also be a project where there is a final product (such as telling a story using Scratch, for example) or a STEAM (Science, Technology, Engineering, Art and Mathematics) initiative. This type of initiative is close to what is known as Project Based Learning (PBL) where students follow a learning path, culminating in the presentation of a project (Trujillo, 2015; Jiménez et al., 2017).

\section{2. e-Proctoring}

Final tests or exams, whether they consist of applying theoretical content or solving practical cases, need to be supervised. When it comes to online assessment and, therefore, to supervising online tests, we speak of e-proctoring, and schools have few resources in this regard. It is true that in the framework of primary education, the framework in which this chapter is developed, e-proctoring techniques should 
not be very complex. Due to the characteristics of the students, it is not advisable to use very invasive techniques.

There are e-proctoring programs, such as Smowl, which is based on artificial intelligence and recognizes the student through biometric control while monitoring desktop activity. Other programs, such as Respondus Lockdown Browser, lock the computer screen, and while it is running, only the institution's e-learning portal can be accessed.

As numerous studies suggest, in primary education, the characteristics of the students and their digital competence is not conducive to use sophisticated techniques (Basogain-Urrutia, 2021). The ideal is to supervise the final tests using videoconferencing, since this allows the student to communicate with the teacher in case there are doubts and there is an open communication channel. Even so, this cannot be done with all students in primary education, since the youngest students cannot develop an evaluation of this style on their own, however, this is appropriate from the age of 8-9 years.

\section{SCHOOL ENGAGEMENT, SCHOOL CULTURE AND E-LEARNING}

School Engagement refers to the way students relate to and become involved in their school. Fredricks et al. (2005) offers a definition of this concept, but many authors have described it and its definition has changed over the years. Yet, this definition (Fredricks et al., 2005) is most accepted by the educational-scientific community, where three types of involvement are distinguished as Ramos-Díaz et al. (2017) and Basogain-Urrutia (2020) explain:

1. Emotional engagement: characterized by collecting all emotional reactions, whether positive or negative, as well as the feeling of belonging to the centre.

2. Behavioural engagement: focuses on the student's participation in school activities; it is also considered essential to achieve good academic results.

3. Cognitive engagement: refers to the effort a learner is willing to make to understand complex ideas and skills. It also refers to the effort to go beyond the minimum required.

School Culture, on the other hand, defines the reality that takes place within the school. Innumerable authors have tried to define it, however, one of the definitions that makes its meaning clearer is the one offered by Deal and Kennedy "the way we do things around here" (Deal \& Kennedy, 1983: 501). It is conceived as a static and at the same time, dynamic entity that concerns the bases of the rules, beliefs and assumptions that govern an institution. It is emphasized that it has a dimension that is not so evident, suggesting that the only way to learn the culture of a school is to be in it. The elements to which school culture concerns are many, since they cover a wide spectrum; thus, Schein (2018), tries to collect some of the elements that compose it, in order to try to understand it better. These are:

- Observable attitudes (includes language and rituals).

- Rules -written and not written- that evolve in work teams. 
- Dominant values, especially those established by the organization.

- The policies of the center.

- The rules.

- The philosophy guiding the policies and standards.

- The school climate.

The inclusion of e-learning as part of the teaching and learning processes is part of the school culture and could affect school engagement levels. It is part of the school culture because in order to move towards a successful e-learning model in schools, it is essential to make it part of the school culture. Teachers and students must conceive of it as a natural element of the school, while acknowledging this is more difficult at the early ages. It is important that the elements of VLE management become cultural elements, since LMS environments are but an extension of the school and not a parallel reality to it.

As an element that can affect the school environment, it is important to consider the pedagogical aspect of e-learning, as well as its management system. Creating elearning environments that are easy to use, efficiently managed and based on the school's pedagogical and curricular models, will move society towards an ideal goal. Since school engagement is concerned with how it relates to its school, it is important that this dimension is considered during the creation and management of the LMS site, but it is also vital to adapt the pedagogical model to the learning environment, virtual in this case, to which it is applied.

That is, if a high cognitive engagement (trying to go beyond what is required) or a high behavioral engagement (participation) is sought, the academic activities developed in the VLE must have been developed taking into account that they will take place in a virtual context. In this aspect, the motivation to learn more and make a greater effort may be related to the instructional design of the virtual classroom. On the other hand, emotional engagement may also be related to the management and appearance of the e-learning site, especially the usability and user experience for younger learners.

\section{CONCLUSION}

The management of an e-learning environment has more dimensions than it seems at first glance. First of all, the more technical part requires certain knowledge and specific management aspects. In addition, it is very important to know the processes that make up the implementation of an e-learning site and its maintenance (enrolling users, creating courses, establishing patterns and rules for its use). Besides that, it is extremely important to master the pedagogical part of e-learning. This is the task of the teacher and not of the site administrator (as opposed to the more technical aspects), and it is important to train teachers in aspects of the use of their LMS sites. To continue with, it is relatively important to delve into all the resources offered by VLEs in order to develop complete, innovative and appropriate activities and assessments for the virtual environment. In this regard, it is not enough to master basic assessment tools such as homework or the online form. It is recommended to try new tools and resources, even testing alternative methods such as discussions or projects. 
Finally, as in most educational processes, it is necessary to expand the focus of attention and look at the school reality from a broader point of view. Although the management of e-learning sites such as Moodle has many technical and precise aspects that require careful study and online assessment offers many tools and methodological alternatives, the school is still an accumulation of interconnected processes, as defined by the school culture.

In this regard, the implementation and management of the VLE should be understood as a cultural element of the school and it is important not to ignore how its use, management and design affect school engagement. Since online learning remains part of the school and pursues specific objectives, it should be understood not only as a means but also as a part of learning itself.

\section{REFERENCES}

A b r e u, J.L. (2020). Tiempos de Coronavirus: La Educación en Línea como Respuesta a la Crisis. Revista Daena (International Journal of Good Conscience), 15(1), 1-15. ISSN 1870557X. http://www.spentamexico.org/v15-n1/A1.15(1)1-15.pdf.

A n a n ga, P. (2020). Pedagogical considerations of e-learning in education for development in the face of COVID-19. International Journal of Technology in Education and Science (IJTES), 4(4), 310-321. https://doi.org/10.46328/ijtes.v4i4.123.

B a s o g a i n - U r r u t i a, J.X. (2021). Evaluación en Línea: Herramientas, Limitaciones y Alternativas en un Contexto de Pandemia. Revista Tecnológica-Educativa Docentes 2.0, 10(2), 30-41. https://doi.org/10.37843/rted.v10i2.243.

B a sog i in Urrutia, J.X. (2020). Eskola-inplikazioa eta eskola kultura: Bermeoko Eleizalde Ikastola. https://addi.ehu.es/handle/10810/50098.

Deal, T.E. \& Ken nedy, A.A. (1983). Culture: A new look through old lenses. The Journal of Applied Behavioral Science, 19(4), 498-505. https://doi.org/10.1177/002188638301900 411.

Fredricks, J.A., Blum en feld, P., Fried el, J., \& Paris, A. (2005). School engagement. In L. Li p m a n (Ed.). What do children need to flourish? (pp. 305-321). Springer. ISBN 978-0-387-23061-0.

Gregori, E.B., \& De Martín Rojo, E. (2011). Porfolio electrónico: aprender a evaluar el aprendizaje. Editorial UOC. ISBN 978-84-9788-851-6.

Ji méne z, C.A., Calderón B adilla, Y., \& Herrero Villar real, D. (2017). Estrategias adicionales de evaluación en una universidad a distancia: ¿alternativas o complementarias al examen escrito? Cuadernos de Investigación UNED, 9(1), 157-164. ISSN 1659-4266. https://www.redalyc.org/jatsRepo/5156/515653587021/515653587021.pdf.

K h a r b at, F.F. \& D a a b e s, A. (2021). E-proctored exams during the COVID-19 pandemic: A close understanding. Education and Information Technologies. https://doi.org/10.1007/ s10639-021-10458-7.

Ló pe z Álva rez, D. (2013). Si elimino el examen ¿mis alumnos dejarán de aprender? Una experiencia de diseño de actividades educativas alternativas al examen. ReVisión, 6(2), 10-17. ISSN 1989-1199. http://hdl.handle.net/2117/20673. 
Moren o, F. \& S a n t i g o, R. (2003). Formación online: guía para profesores universitarios. Logroño: Universidad de la Rioja. ISBN 978-8495301802. https://www.researchgate.net/ publication/39207293.

Pe rió di c o La Ri oja (2019).La UNIR comienza el curso con45.000 estudiantes de90 países. La Rioja. https://www.larioja.com/la-rioja/unir-comienza-curso-20191118110930-nt.html.

Ramos-Díaz, E., Rodríguez-Fernández, A., Ros, I., \& Antonio-Agirre, I. (2017). Implicación escolar y autoconcepto multidimensional en una muestra de estudiantes de secundaria. Revista complutense de educación, 28(4), 113. ISSN 1988-2793. https://revistas.ucm.es/index.php/RCED/article/download/51600/51778.

Ros Martínez de Lahidalga, I. (2008). Moodle, la plataforma para la enseñanza y organización escolar. ISSN 1988-5911. http://hdl.handle.net/10810/6876.

S che i n, E.H. (2018). Organizational Culture and Leadership ( $5^{\text {th }}$ ed.). Wiley. ISBN 978-111 9212041.

Sz u lc, J. (2020). Distance Learning - the Current Status and Directions for Further Research. International Journal of Research in E-Learning, 6(1), 1-19. https://doi.org/10.312 61/IJREL. 2020.6.1.02.

S ol i m a n, N.A. (2014). Using e-learning to develop EFL students' language skills and activate their independent learning. Creative Education. https://doi.org/10.4236/ce.2014.510088.

Universidad Internacional de la Rioja (2021). Misión y valores. https://www.unir.net/universidad-online/mision-valores.

Universidad Internacional de Valencia (2020). Plan adaptación COVID-19 para el curso 2019-2020. https://www.universidadviu.com/download/file/19154. 